\section{АУДИТ ІНФОРМАЦІЙНОЇ БЕЗПЕКИ ПІДПРИЄМСТВА}

\section{ENTERPRISE INFORMATION SECURITY AUDIT}

\author{
ХАДЖИНОВА О. В., \\ доктор економічних наук, \\ професор, декан економічного \\ факультету, \\ КУРТЯНИК М. С., \\ аспірант, \\ ДВНЗ «Приазовський державний \\ технічний університет»
}

\author{
KHADZHYNOVA O., \\ Doctor of Science in Economics, \\ Professor, Dean of the Faculty of \\ Economics, \\ KURTYANIK M., \\ Post-graduate Student, \\ State Higher Educational \\ Institution "State Technical \\ University"
}

\begin{abstract}
У статті визначено, що аудит інформаційної безпеки спрямований виявити і оцінити потенційні проблеми, слабкі місця у функціонуванні інформаційних систем підприємства. Розкрито сутність і зміст видів аудиторських перевірок інформаційної безпеки підприємства. Запропоновано послідовність проведення аудиту інформаційної безпеки підприємства, виділено етапи його проведення, кожен з яких спрямований на забезпечення захисту інформаційної системи підприємства від несанкціонованого доступу при безперервності ведення бізнесу.
\end{abstract}

Ключові слова: інформаційна безпека; інформаційні технології; підприємства; інформаційно-телекомунікаційна система; аудит.

В статье определенно, что аудит информационной безопасности направлен на выявление и оценку потенциальных проблем, слабых мест в функционировании информационных систем предприятия. Раскрыто сущность и содержание видов аудиторских проверок информационной безопасности предприятий. Предложена последовательность проведения аудита информационной безопасности предприятий, выделено этапы его проведения, каждый из которых направлен на обеспечение защиты информационной системы от несанкционированного доступа при непрерывности ведения бизнеса.

Ключевые слова: информационная безопасность; информационные технологии; предприятия; информационнотелекоммуникационная система; аудит.

The article clearly states that information security audit is aimed at identifying and increasing the level of problems, weaknesses in the functioning of enterprise information systems. The essence and content of types of audits of information security of enterprises are disclosed. The sequence of operations of information security of enterprises.

Key words: information security; information technology; enterprises; information and telecommunication system; audit.

Постановка проблеми. Спалах нової коронавірусної інфекції COVID-19 здійснив серйозний вплив на політичне, соціальноекономічне, суспільне життя всього світу. На сьогоднішній день менеджменту підприємств необхідно розробити і прийняти такі управлінські рішення, які дозволять не тільки справлятися з кризовими явищами, викликаними пандемією, але і швидко адаптуватися до незворотних фундаментальних змін. Створення нових можливостей ведення бізнесу, забезпечення сталого розвитку підприємств, зміцнення конкурентоспроможності можливо досягти, впроваджуючи 
новітні розробки в області інформаційних технологій. Системні наукові дослідження виявили, що використання інформаційних технологій спричинило інтеграцію економічних процесів в цифровий простір і вимагають змін традиційних підходів, принципів і методів управління підприємством, зумовлюють необхідність побудови нових моделей системи управління підприємством.

Трансформація економічних процесів стала одним з основних векторів соціально-економічної активності, що призвело до розвитку online-бізнесу, притоку інвестицій, проведення транзакцій через електронну торгівлю, підвищення ефективності розподілу фінансових ресурсів, гнучкості банківських операцій, зростання продуктивності в багатьох розвинених країнах.

Але існує i негативна сторона цифрової трансформації економічних процесів. Недосконала законодавча база, використання застарілої IT-інфраструктури 3 неліцензованим програмним забезпеченням призводить до збільшення несанкціонованого доступу, фальсифікації комерційної таємниці, шахрайських дій 3 ділової електронною поштою, припинення господарської діяльності через несподівані збої інформаційної системи. Перелічені вище негативні наслідки свідчать про зростаючі проблеми управління інформаційною безпекою підприємства в сучасних умовах.

Тому виникає необхідність оцінити поточний рівень інформаційної безпеки, спрогнозувати ризики і загрози хакерських атак і кібертероризму, які націлені на крадіжку цифрових активів підприємства, фальсифікацію, блокування або копіювання конфіденційної інформації, фінансове шахрайство, знищення даних, маніпуляцію бізнес-процесів, приховування слідів, вихід системи зі штатного режиму експлуатації. Потенційно можливі події, які можуть завдати шкоди інформаційним системам можливо нівелювати шляхом регулярного проведення аудиту інформаційної безпеки ITінфраструктури та інформаційної системи підприємства в цілому. Дані заходи дозволять знизити або усунути ризики, загрози, пов'язані 3 витоком комерційної таємниці, зараженням обладнання шкідливим програмним забезпеченням, а також скорегувати систему управління інформаційною безпекою.

Аналіз досліджень і публікацій. У сучасній науковій літературі аудит інформаційної безпеки, представляється як ключовий компонент захисту інформаційної системи підприємства. Питання теоретичної та практичної значущості аудиту інформаційної безпеки знайшли відображення в дослідженнях РояЯ.В., Мазура Н.П., Складніцкого П. М. [1], Юдіа О. К., Зюбіна В. Р., МатвійчукЮдіна О. В. [2], Криворучко О. В., Десятко А. М., Сунічука О. М. [3] та інші.

Однак цифрова трансформація економічних процесів, прискорений розвиток науково-технічного прогресу, збільшення загроз розкриття конфіденційної інформації і комерційної таємниці підприємства вимагають подальшого дослідження аудиту інформаційної безпеки, забезпечення безпеки інформаційних активів підприємства.

Мета статті - запропонувати поетапний процес аудиту інформаційної безпеки, який надійно забезпечить захист інформаційної системи підприємства від несанкціонованого доступу. 
Виклад основного матеріалу. Сьогодні інформаційні технології відіграють значну роль в забезпеченні ефективного виконання бізнеспроцесів суб'єктів господарювання. Повсюдне використання інформаційних технологій в діяльності підприємств обумовлює необхідність вирішувати проблеми, пов'язані із захистом даних. Головною метою будь-якої системи забезпечення інформаційної безпеки має бути створення необхідних умов функціонування підприємства, запобігання загрозам його безпеки, захист законних інтересів підприємства від протиправних посягань, недопущення розкрадання фінансових коштів, розголошення, втрати, витоку, перекручування та знищення службової інформації. Для оцінки стану інформаційної інфраструктури підприємства і розробити методи, за допомогою яких можна було 6 досягти відповідності стану інформаційної інфраструктури потребам бізнесу, а також для досягнення інформаційної безпеки в сучасному світі служить аудит інформаційної безпеки.

Аудит інформаційної безпеки - ключова складова для правильного функціонування всієї інформаційної системи підприємства. Він спрямований на об'єктивну, незалежну і всебічну оцінку ефективності, результативності, адекватності системи менеджменту і заходів інформаційної безпеки підприємства. Він дозволяє виявити слабкі місця, уразливості, недоліки, потенційні проблеми у функціонуванні та реалізації системи менеджменту інформаційної безпеки. Крім того, за результатами проведеного аудиту розробляються пропозиції щодо модернізації та уніфікації ITінфраструктури із забезпечення інформаційної безпеки підприємства. Дані заходи сприяють створенню культури постійного вдосконалення суб'єкта господарювання.

Основними цілями при проведенні аудиту інформаційної безпеки підприємства $€$ оцінка коректності постановки задачі інформаційної безпеки підприємства в розрізі бізнес-завдань, у тому числі правових зобов'язань; аналіз реалізації завдань і контролю інформаційної безпеки; аналіз виконання завдань інформаційної безпеки співробітниками організації.

Таким чином, аудит інформаційної безпеки - це комплексне дослідження і оцінка системи управління інформаційною безпекою підприємства, яка дозволяє перевірити ефективність, результативність, адекватність системи менеджменту, відповідність інформаційних систем міжнародним стандартам збору, зберігання, знищення конфіденційної інформації, а також стан безпеки всієї ITінфраструктури підприємства: обладнання, центрів обробки даних, програмного забезпечення, мереж, послуг.

Комплексний аудит інформаційної безпеки об'єднує певну кількість видів аудиторських перевірок інформаційної безпеки підприємства (рис. 1).

Аудит системи менеджменту інформаційної безпеки оцінює відповідність реалізованих заходів інформаційної безпеки та впровадженої системи менеджменту стандарту ISO/IEC 27001:2014 «нфформаційні технології. Методи безпеки. Системи менеджменту інформаційною безпекою. Вимоги». [4].

Аудит системи менеджменту інформаційної безпеки (СМІБ) дає можливість формулювати рекомендації 3 управління інформаційною безпекою. Він дозволяє перевірити і модернізувати програмне забезпечення всеосяжного процесу управління інформаційною 
безпекою, систематично оцінювати ризики IT-архітектури 3 урахуванням впливу загроз і вразливостей для підприємства.

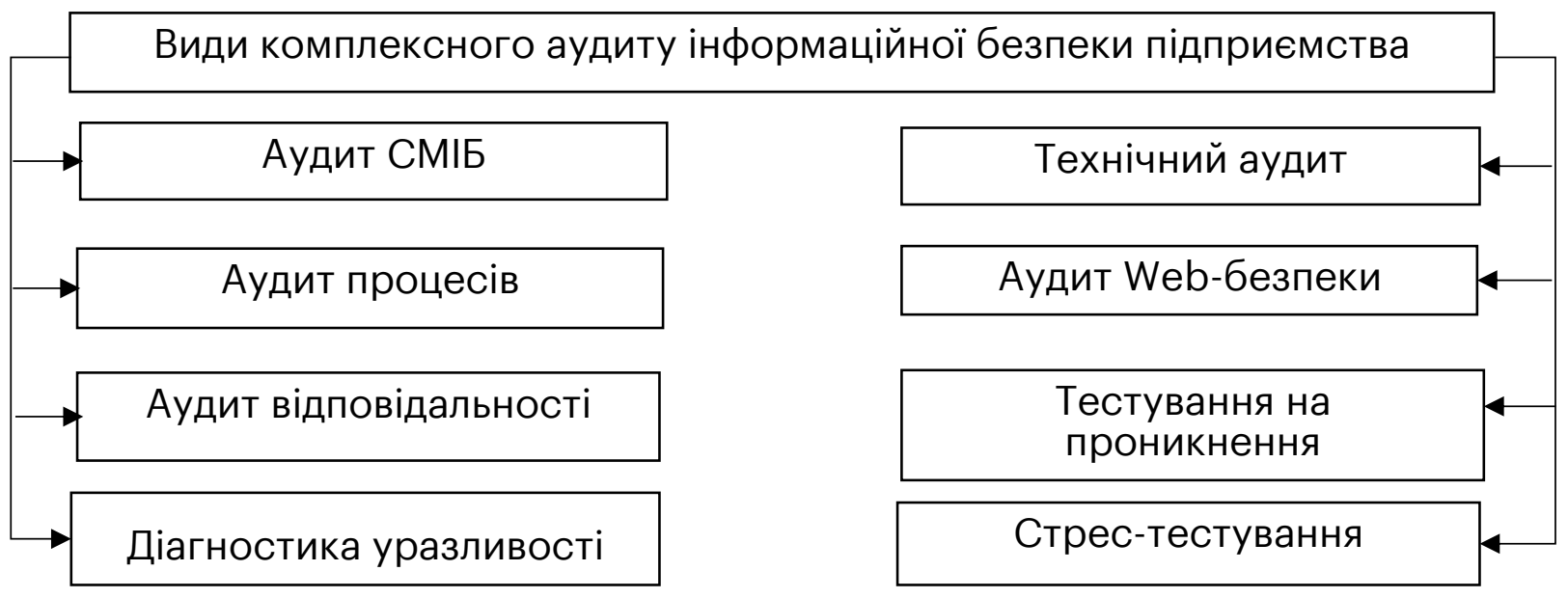

Рис. 1. Види аудиту інформаційної безпеки підприємства

У процесі технічного аудиту перевіряються настройки інформаційної системи або її частин у відповідності 3 існуючими рекомендаціями виробників або міжнародно визнаних організацій таких як NISIT, CIS, NSA та ін. Цей вид аудиту необхідно поєднувати 3 аудитом процесу. Це якщо виявлено недостатнє виправлення контролерів домену та процес управління вразливостями не працює.

В рамках «аудиту процесів» перевіряються настройки процесів, які використовує підприємством для забезпечення інформаційної безпеки. Це можуть бути процеси контролю доступу пов'язаних з управлінням конфігурацією, управлінням вразливостями та іншими ITопераціями.

Аудит web-безпеки запобігає фальсифікації, знищенню, витоку інформації і викликані, як правило, web-додатками. Даний вид аудиту інформаційної безпеки надає комплексні рішення, пов'язані 3 виявленням різних вразливостей web-додатків, запобіганням несанкціонованого доступу програмного забезпечення по мережі Інтернет та інше.

Аудит відповідності інформаційної безпеки підприємства міжнародним стандартам ISO вважається аудитом високого рівня. Він складається з передових практик в області інформаційної безпеки. Відповідні вимоги до проведення аудиту відображені в міжнародних стандартах ISO/IEC:17799 «/нформаційні технології. Управління інформаційною безпекою» [5], ISO/IEC 27001:2015 «Інформаційні технології. Методи забезпечення безпеки. Системи управління інформаційною безпекою. Вимоги» [6], державних стандартів ДСТУ 3396.1-96 «Захист інформації. Технічний захист інформації. Порядок проведення робіт», а також в законодавчій базі України в сфері захисту інформації [7]. Даний вид аудиту перевіряє ступінь відповідності інформаційної системи підприємства стандартам ISO 27000, а також внутрішнім вимогам в області забезпечення інформаційної безпеки.

Таким чином аудит відповідності $\epsilon$ систематичним процесом перевірки документації, яка показує наскільки точно підприємство виконує закони, нормативно-правові акти та міжнародні стандарти ISO в галузі інформаційної безпеки. 
Наступний вид аудиту інформаційної безпеки підприємства називається тест на проникнення. Він дозволяє перевірити вразливі галузі інформаційної системи шляхом імітації злому і проникнення всередину сервера бази даних, сервера аутентифікації, сервера додатків і інших систем, намагаючись обійти або відключити функції безпеки.

Іншим видом аудиту інформаційної безпеки $є$ діагностика уразливості. Вона полягає в діагностиці операційної системи, мережі, web-додатків, проміжного програмного забезпечення на наявність вразливостей. Виконавши цю діагностику встановлюється статус інформаційної безпеки шеb-додатків, мережі, сервера, а також нівелюються ризики несанкціонованого доступу до сайтів і додатків підприємства, здійснюється запобігання витоку інформації шляхом виявлення проблем безпеки.

Стрес-тестування $€$ ще одним видом аудиту інформаційної безпеки підприємства. Він допомагає підприємству швидко за допомогою проведення online-тестів діагностувати здатність інформаційної системи захищатися від хакерських атак, несанкціонованого доступу, з якими стикаються підприємства при здійсненні господарської діяльності в інтернет просторі.

Таким чином, вищезазначені види аудиту інформаційної безпеки підприємств сприяють комплексному захисту інформаційних систем, web-додатків, програмного забезпечення. Вони перевіряють вразливі галузі інформаційної системи шляхом імітації злому сервера бази даних, сервера аутентифікації, сервера додатків.

Аудит інформаційної безпеки проводяться відповідно до процедур визначені у стандартах ISO/IEC 27007 - ISO/IEC 27009. На рисунку 2 показані різні етапи аудиту системи менеджменту інформаційної безпеки.

\begin{tabular}{|c|c|}
\hline І етап & $\begin{array}{l}\text { Ініціатива керівництва, щодо аудиту інформаційної } \\
\text { безпеки }\end{array}$ \\
\hline II етап & Розробка плану аудиту інформаційної безпеки \\
\hline III етап & Проведення аудиту інформаційної безпеки \\
\hline & $\begin{array}{l}\text { - обстеження обчислювальної системи; } \\
\text { - обстеження інформаційного середовища; } \\
\text { - обстеження фізичного середовища; } \\
\text { - обстеження середовища користувачів; } \\
\text { - тестування на уразливості; } \\
\text { - аналіз захищеності інформаційно-телекомунікаційної } \\
\text { системи. }\end{array}$ \\
\hline IV етап & Складання аудиторського звіту \\
\hline
\end{tabular}

Рис. 2. Етапи аудиту інформаційної безпеки підприємства 
На першому етапі відбувається ініціювання аудиту інформаційної безпеки топ-менеджментом підприємства. Начальник служби безпеки призначає аудитора інформаційної безпеки, чітко визначає його права і обов'язки, встановлює завдання і мету аудиту. Аудитор несе повну відповідальність за якість і ефективність проведеного аудиту. Він повинен мати достатні знання, навички в галузі забезпечення інформаційної безпеки, щоб виявляти і мінімізувати ризики, загрози, пов'язані з програмою аудиту. Аудитор зобов'язаний вміти визначати обсяг і цілі, вибирати і використовувати відповідні інструменти, а також методи аудиту.

На другому етапі здійснюється розробка плану аудиту, що має забезпечити ефективний і результативний аудит інформаційної безпеки підприємства (рис. 3). В рамках однієї аудиторської перевірки неможливо охопити всі напрямки інформаційної безпеки підприємства, тому аудит потрібно планувати на певний період, приблизно на три роки. Середньостроковий план - це документ, в якому описуються такі елементи як: цілі та обсяг аудиту, політика аудиту інформаційної безпеки, приблизний період реалізації і частота перевірок протягом певного періоду. Середньостроковий план аудиту інформаційної безпеки необхідно затвердити на раді директорів.

$\begin{gathered}\text { Середньостроковий } \\ \text { план }\end{gathered} \rightarrow$ Річний план
$\rightarrow$
$\begin{aligned} & \text { План реалізації аудиту } \\ & \text { інформаційної безпеки }\end{aligned}$

Рис. 3. Процес розробки плану аудиту інформаційної безпеки підприємства

В останні роки відбувається інтенсивний розвиток інформаційних технологій, комп'ютерної техніки і систем телекомунікацій, програмного забезпечення для локальних і глобальних мереж, що вимагає постійного оновлення інформаційних систем управління підприємством. Постійне оновлення і зміни мають бути контрольованими і здатними забезпечити збереження інформаційної безпеки підприємства. Тому необхідно проведення системного 3 певною періодичністю аудиту в поточному році. Річний план - це документ аудиту інформаційної безпеки, який складається на основі середньострокового плану, на початку фінансового року. У ньому описуються мета, пріоритети аудиту, кількість і час впровадження інноваційних інформаційних систем.

При визначенні та виборі мети, теми аудиту необхідно розглядати ті складові інформаційних систем, мереж і цифрових активів, які мають більш високу важливість, терміновість і ступінь уразливості, схильність до ризиків і погроз з боку хакерських атак. Необхідність впровадження нових інформаційних систем має бути документально обґрунтовано. Річний план також необхідно затвердити на раді директорів.

Аудитор інформаційної безпеки формулює конкретний план проведення аудиту на основі річного плану. У плані реалізації аудиту може бути описаний рівень основної класифікації і середня класифікація елементів аудиту інформаційної безпеки. Крім того, можуть бути описані застосовні міжнародні стандарти ISO в галузі управління системами інформаційної безпеки. 
Керівник служби безпеки приймає план проведення аудиту, що потім затверджується на раді директорів. Після затвердження плану аудиту інформаційної безпеки радою директорів, керівник служби безпеки інформує відділ, що перевіряється, про терміни перевірок, призначає відповідальну особу, запитує матеріали попереднього аудиту, вносить корективи для ефективного проведення перевірок.

Третій етап аудиту інформаційної безпеки підприємства $є$ найбільш складним процесом. Щоб результативно i ефективно провести даний аудит необхідно використовувати основні методи аудиту: інтерв'ю, огляди, опитування і перевірки. Зазначені методи мають бути задокументовані і можуть використовуватися не тільки на підприємстві, але також для віддалених аудитів інформаційної безпеки підприємства.

Ha етапі аудиту інформаційної безпеки підприємства проводиться комплексне обстеження інформаційнотелекомунікаційної системи: обстеження обчислювальної системи, обстеження інформаційного та фізичного середовища, середовища користувачів, тестування на уразливості.

В ході обстеження обчислювальної системи організації описується:

- наявність документації на інформаційно-телекомунікаційну систему та її компоненти (паспорт інформаційно-телекомунікаційної системи);

- загальна структурна схема інформаційно-телекомунікаційної системи та її склад (перелік і склад устаткування, технічних та програмних засобів, їх зв'язку, особливості конфігурації, архітектури та топології, програмні та програмно-апаратні засоби захисту інформації, взаємне розміщення коштів);

- види і характеристики каналів зв'язку;

- особливості взаємодії компонентів інформаційнотелекомунікаційної системи;

- можливі обмеження щодо використання коштів.

Крім того, при обстеженні обчислювальної системи інформаційно-телекомунікаційної системи підприємства мають бути виділені компоненти, які є засобами захисту інформації або містять механізми захисту. А саме, мають бути описані потенційні можливості цих засобів і механізмів, їх властивості та характеристики, в тому числі ті, які встановлюються за замовчуванням.

При обстеженні інформаційного середовища підприємства описуються:

- характеристика інформації, що обробляється;

- види інформації, які циркулюють в інформаційнотелекомунікаційній системі, і вимоги щодо ії захисту;

- типи об'єктів, в яких інформація зберігається;

- особливості технології обробки інформації;

- схеми інформаційних потоків;

- режими доступу до інформації;

- носії інформації та порядок роботи з ними.

При обстеженні фізичного середовища інформаційнотелекомунікаційної системи увага приділяється таким характеристикам: 
- територіальне розміщення компонентів інформаційнотелекомунікаційної системи (генеральний план, ситуативний план);

- наявність території, що охороняється і пропускного режиму на підприємстві; компоненти;

- наявність категорійних приміщень, в яких розміщуються

- наявність охоронної та пожежної сигналізації, систем відеоспостереження і контролю доступу в приміщення;

- режим доступу до компонентів фізичного середовища інформаційно-телекомунікаційної системи;

- вплив факторів навколишнього середовища на захищеність інформації;

- наявність в приміщеннях, де функціонує інформаційнотелекомунікаційна система, елементів комунікацій, систем життєзабезпечення та зв'язку, що мають вихід за межі контрольованої території;

- умови зберігання магнітних, оптико-магнітних, паперових та інших носіїв інформації;

- наявність проєктної та експлуатаційної документації на компоненти фізичного середовища.

При проведенні обстеження середовища користувачів описується:

- наявність розпорядчих документів, що регламентують діяльність персоналу підприємства, щодо забезпечення безпеки інформації в інформаційно-телекомунікаційній системі;

- наявність служби (підрозділу) захисту інформації, іï функції і повноваження;

- функціональний і кількісний складу користувачів інформаційно-телекомунікаційної системи підприємства, їх функціональні обов'язки і рівень кваліфікації;

- $\quad$ категорії користувачів за рівнем їх повноважень;

- повноваження користувачів щодо організації доступу до відомостей, які обробляються в інформаційно-телекомунікаційній системі;

- повноваження користувачів 3 управління коштами або механізмами захисту в інформаційно-телекомунікаційній системі.

При тестуванні на уразливості проводиться сканування всіх компонентів інформаційно-телекомунікаційної системи 3 використанням при необхідності тестів на проникнення.

На етапі аналізу захищеності виконується аналіз і систематизація отриманих результатів обстеження, ідентифікація виявлених вразливостей і оцінка рівня захищеності інформаційнотелекомунікаційної системи підприємства.

За результатами проведеного аналізу захищеності інформаційнотелекомунікаційної системи формується звіт, i розробляються рекомендації 3 нейтралізації виявлених вразливостей. Для цього при проведенні аудиту ведеться протокол загроз i вразливостей інформаційної безпеки підприємства. Крім того, отримана інформація про хід аудиторської перевірки, є закритою інформацією і не має бути передана нікому, крім керівництва підприємства. 
На основі протоколу аудиту готується аудиторський звіт в якому вказується рівень ефективного функціонування робочого циклу, ступінь уразливості інформаційних активів, мереж, і в цілому інформаційної системи до кібератак з метою крадіжки інтелектуальної власності, відображаються заходи захисту інформації від хакерських атак. Крім того, аудитором надаються рекомендацій із модернізації і розвитку інформаційної системи підприємства, а також підвищення ефективності іï функціонування. Ґрунтуючись на результатах проведеного аудиту, менеджмент ініціює заходи 3 модернізації системи управління інформаційною безпекою підприємства.

Висновки і перспективи подальших досліджень. Таким чином, аудит інформаційно-телекомунікаційної системи підприємства дає керівникові компанії об'єктивну оцінку її поточного стану, процесів і подій, пов'язаних 3 іï функціонуванням, дозволяє визначити відповідність інформаційної системи вимогам менеджменту підприємства до інформаційного забезпечення бізнес-процесів. В процесі проведення робіт підприємство отримує формалізовані описи існуючої інформаційної архітектури, зв'язок програмно-апаратної архітектури інформаційної системи 3 роботою відповідних технологічних і функціональних підрозділів підприємства.

Аудит інформаційної безпеки спрямований на незалежну всебічну оцінку ефективності, результативності, адекватності системи управління інформаційною безпекою. Аудит інформаційної безпеки спрямований на створення централізованих систем контролю доступу, захист системи управління підприємством, забезпечення безперервності бізнесу, створення функції по боротьбі з хакерськими атаками, отримання незаконних доходів і шахрайством. Проведення кваліфікованого аудиту інформаційної безпеки підприємства i виконання комплексу заходів із захисту інформаційних ресурсів за рекомендаціями, що розроблені в результаті такого аудиту, дає впевненість в захищеності інформаційно-телекомунікаційної системи на певний період. Оскільки високі технології розвиваються динамічно, і разом з ними удосконалюються засоби вчинення злочинів у сфері IT, аудит інформаційної безпеки підприємства слід проводити періодично і на більш технологічно досконалому рівні. Тільки при такому підході аудит буде приносити позитивний ефект і сприяти підвищенню рівня інформаційної безпеки підприємства.

1. Рой Я. В., Мазур Н.П., Складанний П. М. Аудит інформаційної безпеки - основа ефективного захисту підприємства. Кібербезпека: освіта, наука, техніка. 2018. № 1. С. 86-93. URL: http://nbuv.gov.ua/UJRN/cest 2018111.

2. Юдін О. К., Зюбіна Р. В., Матвійчук-Юдіна О. В. Сучасні практики впровадження системи аудиту інформаційної безпеки на об'єктах критичної інфраструктури. Наукоємні технології. 2019. № 1. C. 36-43. URL: http://nbuv.gov.ua/UJRN/Nt 201917.

3. Криворучко О. В., Десятко А. М., Сунічук О. М.Моделювання інформаційної системи проведення незалежного аудиту інформаційної безпеки Управління розвитком складних систем. 2020. Вип. 43. C. 67-75. URL: http://nbuv.gov.ua/UJRN/Urss 20204312.

4. ДСТУ ISO/IEC 27001:2014. Інформаційні технології. Методи безпеки. Системи менеджменту інформаційною безпекою. Вимоги (ISO/IEC 27001:2013;ISO/IEC 27001:2013/Cor 1:2014;IDT). 
5. ДСТУ ISO/IEC: 17799. Інформаційні технології. Управління інформаційною безпекою.

6. ДСТУ ISO/IEC 27001:2015. Інформаційні технології. Методи захисту. Системи управління інформаційною безпекою. Вимоги (ISO/IEC 27001:2013; Cor 1:2014, IDT).

7. ДСТУ 3396.1-96. Захист інформації. Технічний захист інформації. Порядок проведення робіт.

\section{References:}

1. Roj Ja. V., Mazur N. P., Skladannyj P. M. Audyt informacijnoji bezpeky - osnova efektyvnogho zakhystu pidpryjemstva. Kiberbezpeka: osvita, nauka, tekhnika. 2018. \# 1. S. 86-93. URL: http://nbuv.gov.ua/UJRN/cest_2018_1_11.

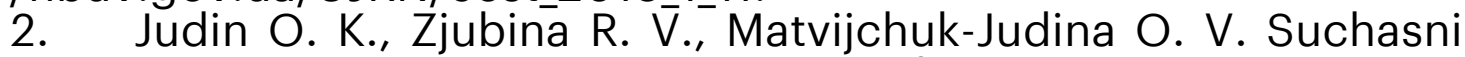
praktyky vprovadzhennja systemy audytu informacijnoji bezpeky na ob'jektakh krytychnoji infrastruktury. Naukojemni tekhnologhiji. 2019. \# 1. S. 36-43. URL: http://nbuv.gov.ua/UJRN/Nt_2019_17.

3. Kryvoruchko O. V., Desjatko A. $\bar{M}_{\text {., }}$ Sunichuk O. M. Modeljuvannja informacijnoji systemy provedennja nezalezhnogho audytu informacijnoji bezpeky Upravlinnja rozvytkom skladnykh system. 2020. Vyp. $43 . \quad$ S. 67-75. URL: http://nbuv.gov.ua/UJRN/Urss_2020_43_12.

4. DSTU ISO/IEC 27001:2014. Informacijni tekhnologhiji. Metody bezpeky. Systemy menedzhmentu informacijnoju bezpekoju. Vymoghy (ISO/IEC 27001:2013;ISO/IEC 27001:2013/Cor 1:2014;IDT).

5. DSTU ISO/IEC: 17799. Informacijni tekhnologhiji. Upravlinnja informacijnoju bezpekoju.

6. DSTU ISO/IEC 27001:2015 Informacijni tekhnologhiji. Metody zakhystu. Systemy upravlinnja informacijnoju bezpekoju. Vymoghy (ISO/IEC 27001:2013; Cor 1:2014, IDT).

7. DSTU 3396.1-96. Zakhyst informaciji. Tekhnichnyj zakhyst informaciji. Porjadok provedennja robit.

The purpose of the article is to propose a stepwise information security audit process that will reliably protect the enterprise information system from unauthorized access.

Information security audit is an effective mechanism that plays a key role in protecting the entire IT infrastructure of an enterprise. Information security audit is aimed at an objective, independent and comprehensive assessment of the effectiveness, efficiency, adequacy of the management system and information security measures of the enterprise. It allows you to identify weaknesses, vulnerabilities, shortcomings, potential problems in the operation and implementation of the information security management system. Based on the results of the audit, proposals are being developed for the modernization and unification of the IT infrastructure to ensure the information security of the enterprise. These activities contribute to the creation of a culture of continuous improvement of the enterprise.

When conducting an audit of the information security of an enterprise, a comprehensive survey of the information and telecommunications system is carried out: a survey of a computer 
system, a survey of the information and physical environment, user environment, testing for vulnerabilities.

During the audit, a protocol of threats and vulnerabilities of the enterprise's information security is kept. Based on the audit protocol, an audit report is prepared, which indicates the level of effective functioning of the working cycle, the degree of vulnerability of information networks, and reflects the measures to protect the information of the enterprise. In addition, recommendations are provided for the modernization and development of the enterprise information system, as well as improving the efficiency of its functioning.

Conducting a qualified audit of the information security of an enterprise and implementing a set of measures to protect information resources according to the recommendations developed as a result of such an audit, gives confidence in the security of the information and telecommunications system for a certain period.

УДК 336.226.2

DOI: $10.35340 / 2308-104 X .2021 .90-1-07$

\section{ОСОБЛИВОСТІ ЗЕМЕЛЬНОГО ОПОДАТКУВАННЯ В УКРАЇНІ}

СЕМКОВА Л. В., кандидат економічних наук, доцент Маріупольський гуманітарний університет

\section{FEATURES OF LAND TAXATION IN UKRAINE}

\author{
SEMKOVA L., \\ $\mathrm{PhD}$ in Economics, \\ Associate Professor \\ Mariupol State University
}

В статті визначено сутність та економічний зміст земельного оподаткування. Зазначено, що земельний податок є одним з джерел поповнення місцевих бюджетів та державного бюджету. Визначено осіб платників земельного податку та терміни сплати даного виду податку. Розглянуто на прикладі Донецької області плату земельного податку відповідно до встановлених норм у 2021 році. Наведено алгоритм розрахунку земельного податку. Охарактеризовано особливості та правила складання декларації з сплати за землю. Визначено категорії осіб та категорії земель, які звільнено від сплати земельного податку.

Ключові слова: земля, земельний податок, місцевий та державний бюджет, алгоритм оподаткування, декларація, пільги.

В статье определена сущность и экономическое содержание земельного налогообложения. Указано, что земельный налог является одним из источников пополнения местных бюджетов и государственного бюджета. Определены плательщики земельного налога и сроки уплаты данного вида налога. Рассмотрено на примере Донецкой области плату земельного налога в соответствии с установленными нормами в 2021 году. Приведен алгоритм расчета земельного налога. Охарактеризованы особенности и правила составления декларации по плате за землю. Определены категории лиц и категории земель, которые освобождаются от уплаты земельного налога.

Ключевые слова: земля, земельный налог, местный и государственный бюджет, алгоритм налогообложения, декларация, льготы. 